\title{
Organization and Service
}

\author{
John ALden
}

I SPEAKING on the problem of the organization of a university rare book room I am tempted to take as my text a statement I find in André Gide's Pages de Journal: "As soon as I do not differ, I keep silence." This is not to emphasize differences for the sake of differing, but is a recognition of the fact that there is little point to rehearsing those things upon which we all agree.

The questions on which I am to speak are closely related to the basic precepts discussed by Mr. Wyllie and Mr. Powell. Obviously the objectives of the organization of a rare book collection are but the activation of the philosophy and the purposes of such a collection.

My own "philosophy" of the rare book collection embodies in part an element of regret. I find it unfortunate that such a setup is necessary. The rare book collection places, in many ways, a false emphasis upon certain types of material, and distorts the general purposes of a university library when more or less arbitrarily chosen classes of books must be segregated for special treatment among traditionally lush surroundings. Would it not be better for all concerned if it were not necessary to have rare book collections at all? But the day when they will not be called for is not yet with us. It will require, progressively through the ranks of the library ladder, stack boys who respect books as physical objects, catalogers who can discriminate between the relative importance of cataloging details; reference assistants who see books as more than answers to readers' questions, and even library administrators who have the courage to make qualitative rather than quantitative comparisons.

I do not mean to imply, however, that the entire university library should be run like a rare book collection. But only by setting up a rare book collection have we so far found the means of facing the problems created by the need for the special treatment of rare books in the face of the leviathan which the great university library has become. The very bulk of a sizeable research library loosens and demoralizes its standards, and to offset this the university librarian has happily recognized-or been shamed into recognizing-his responsibility to certain types of books, namely, those books, "those treasures whose emotional and intellectual values are so high that they are difficult to compute," to use one definition of the phrase "rare books."

The establishing of techniques which minimize the personal element is apparently essential to the functioning of a huge institution, but the elimination of such personal elements, as far as a rare book collection is concerned, is a loss rather than an advantage. In the rare book collection a knowledge of techniques is far less significant than individual intelligence, and it is to preserve such factors that my own organization is designed. This is rather hard on the person concerned with supplying candidates for my staff positions, who finds it difficult to accept my insistence that I am more interested in intellectual potentialities 
than in the technical equipment of my staff. On the other hand, I am prepared to accept the concomitant responsibility for their training and morale.

While in theory I do believe that the university library should be an integrated whole, my own experience-and I do not speak necessarily in terms of the University of Pennsylvania-has convinced me that the ideal organization of a rare book collection is that of a smaller library set up within the larger unit, a microcosm of its own. By such a means we can perhaps overcome the vices inherent to the large institution and reestablish certain values which have been lost in the burgeoning of our university libraries. This solution will shock the administrator who has succumbed to a faith in mass-production methods. But in practice such an organization of the rare book collection on a smaller scale can and does work. It neither implies nor requires an obliviousness to the over-all integration of the library as a whole. It simply reasserts the validity of certain objectives: those of personal responsibility, initiative, and interest. If it cannot work, then I am in favor of establishing the rare book collection in a separate building, with a completely independent administration.

Put into practice, such organization begins with the primary steps in the library machinery, the acquisition of books. Theoretically, the acquisitions department should have control over all orders, yet this is at the cost of incredible red tape, starting with the searching of titles where established routines necessitate the pursuit of predetermined steps, without reference to the specific problem at hand.

By initiating and handling its own orders for books, the rare book collection can make use of practices which, if carried out on a large scale, would bring forth chaos. Employed profitably by a smaller unit, they can be highly effective. Books sent on approval by dealers, for instance, can be examined before drawing up the inevitably complicated formal orders. More intimate and personal relationships between the rare book collection and dealers permit informalities intolerable to large organizations. Because one knows one's collections, or because, as a specialist, one knows the most expeditious means of verifying authors and titles, one can eliminate much of the time-consuming steps of searching. Once the book is in the library, and there is no question of its desirability, it can then be submitted to the acquisitions department for actual purchase, with the hope that there the book will not be submitted to an orgy of book stamps, perforations, or other marks of library ownership, before being returned to the rare book collection.

Similarly I am convinced that the cataloging of rare books should be done not by the general catalog department, but within the rare book collection. It is a basic tenet of mine that the catalog of a rare book collection is one of its most valuable assets. In the breakdown of American cataloging in our time, we must rescue the rare book from the fate of simplified cataloging. Within the narrower scope of a rare book collection there is some chance of maintaining certain standards and of achieving bibliographic cataloging. Here, too, we can provide those auxiliary date, imprint, or ownership catalogs which are increasingly useful to 
the scholar, which fall outside the usual scope of garden-variety cataloging, and the provision of which complicates the work of the general cataloger.

My reasons for believing that rare book cataloging should be done within the collection are numerous. Not the least of them is that most catalogers do not like to catalog rare books. The fact that a book is "rare" too often throws them into a state of terror. They frequently either feel that they must spend as much time on it as possible, or else they resent the inroads working on it will make on their statistics.

Set up within the rare book collection, many positive advantages accrue to the cataloging of such books. Not the least of these is in terms of morale-and need I say that the mental health of catalogers is a major problem? Working as a part of a smaller unit, the cataloger is given a greater sense of importance, of accomplishment, and of responsibility. Here, too, a higher level of skill and a bibliographical point of view, which should direct rare book cataloging, can be fostered. Rare book cataloging can be thoroughly exciting, as I have discovered not only in myself but in my staff. Believing that some experience in actual cataloging is useful even for those not regularly engaged in it, I have eventually found it necessary to restrain members of my staff from doing cataloging at the expense of other duties.

And, so organized within the collection, rare book cataloging need not be disproportionately time-consuming or costly. In at least one rare book catalog department far more books, proportionately speaking, are much more fully cataloged than in the general catalog department of that university's library: the result of better morale, enthusiasm, competence, and discrimination. Nor does a separate catalog department necessitate a breakdown of coordination and uniformity. If the same forms of entry and of subject headings are employed, wide latitude in the actual contents of the catalog card can be tolerated.

Once the rare book has been processed, its care and service are again facilitated by the smaller scale of the rare book collection. One can know more fully its resources, and keep them in order and in condition. It is, however, conceivable that too much has been made of the rare book collection as a museum for books, with its aura of noli me tangere, but at the same time it is essential to a rare book collection that a decent respect for books as physical objects shall be taught, not merely to students but to the faculty as well. The scholar's distaste for the excesses of sentimentality and of fetishism exhibited by extreme bibliophiles is not always without foundation, yet even the scholar is on occasion equally unreasonable. We all know the type of faculty member for whom the text of a book is alone of importance, and who is blind to its other values. There is room for a companion piece to Randolph Adams' essay on librarians as enemies of books. An essay, in turn, on the scholar as an enemy of books would be well justified. I have even suggested to Mr. Adams that he should write it.

In the rare book room, then, one must educate the users of books in their proper care, starting with the undergraduate who shelves books for you. He will, unless he is exceptional, have to be taught not to pull books from the shelves 
by the tops of their spine, ruining their backstrip, and not to force books onto crowded shelves to avoid shifting. Readers must be taught not to take notes writing on the surfaces of books, and so on.

Yet a formidable number of rules and regulations for their own sake is less important, I think, than constant supervision and close acquaintance with the users of the books. My one rule, that pencil rather than pen shall be used in taking notes, is, I suspect, less important in itself than in its psychological effect, implying as it does-or should-that rare books are to be used with special consideration. Likewise a personal knowledge of users and of use, more than rules and bars, will protect books from mutilation and even theft.

Basically, then, the formal organization of a rare book collection need not differ essentially from that of any small special collection. I am less interested in and less concerned with the formulas and routines which may be established than in the spirit in which the collection is administered. With proper personnel, with the desire to make it function, any technique will work, if its application is limited in scope. Thus it is not in the organization itself, but in its purpose and motivation that a rare book collection is distinctive.

That purpose, that motivation, is the result of the relation of the rare book collection to scholarly research within the university and the community.

In such a scheme I am afraid that the undergraduate generally plays a small part, unless he be the exceptional person with special interests, or actually doing original research of graduate caliber. Certainly the undergraduate who is concerned merely with reading an assigned text as such has little place in the rare book collection, though when the unusual undergraduate appears he should be given every encouragement.

It is, instead, for the graduate student and the faculty, within the compass of the university, that the rare book collection is principally designed. Here will be found the most productive area of service and education, and of the two I think that it is ordinarily the graduate student rather than the professor who will profit the more. This is, unfortunately, not necessarily for the reason that the full professor has already obtained full status as a competent scholar.

For the graduate student the so-called courses in bibliography-which are too often little more than elementary courses in reference tools-or in methods of research obviously do not meet all of the actual needs of the student. Here the curator of rare books can frequently supplement the work of the faculty by giving specific advice and direction, in terms of the resources of other libraries and collections, and in means of approach. .I may be naïve, but I am amazed-although I am also gratified at being of service-at the number of graduate students with whom I find myself sitting down and working out research programs, showing them shortcuts, initiating them into the mysteries of photostats and microfilms, and the like. Nor do I think that this is needlessly pampering the graduate student who is being allowed to sink or swim by haphazard methods of research. The graduate school should certainly provide instruction in effectiveness rather than in trial and error. 
In the field of rare books themselves there is in our generation a particular challenge and appeal. The rise of quasi-scientific bibliography to its present status has given to the rare book collection an importance which it has hitherto lacked. I shall not trace for you here the revolution in literary scholarship of the past forty or so years which has resulted from the work of men such as W. W. Greg and R. B. McKerrow. Suffice it to say that the bibliographical approach to books - that is, the study of them as physical objects-has undermined many previous beliefs, and opened up new areas and techniques of research. In the field of Elizabethan and Restoration literature, for example, the results have been tremendous. In its fullest and richest sense, bibliography has provided a new stimulus to literary and historical scholarship, similar to that provided two generations ago by philology. Unfortunately many faculty members still live in a philological world and are yet unaware of the implications of bibliography. I need but cite the members of an English department who knew nothing of Carter and Pollard's work on Mr. T. J. Wise's forgeries, despite its effect on their own field. There is also the distressing instance of the scholar preparing a variorum edition of Milton which, because of his ignorance of bibliographical principles and practices, has recently brought forth such criticism as to discredit thoroughly his inept if laborious efforts. Ultimately bibliography may prove as stultifying as philology, but in our day it offers magnificent potentialities.

In contemporary bibliographical research the library, and particularly the rare book collection, has thus become more than ever a laboratory, and here the curator of rare books and his staff are of primary importance. It is essential that the curator be, above all, a bibliographer. By this I mean much more than just being a member of the Bibliographical Society of America. He must know what has been done and what is being done in the field of bibliography and put his knowledge to the service of the scholar, especially since in this country there is little opportunity for obtaining sound bibliographic training in either classroom or seminar. At this point most bibliographers are self-made. It is to the rare book collection rather than to the faculty member, more often than not, that the student, faced with a bibliographical problem, must come for guidance, and the faculty member himself is likely to come to the rare book collection for assistance in a technique he frequently understands imperfectly.

Similarly the rare book collection is likely to become the focus for much of the bibliographical research and activity in the community, going beyond the scope of the university itself. The rare book room can readily and properly become the center and clearing house for much of the bibliographical work and research being done by book collectors and other individuals outside the university. By contacts with private collectors, moreover, the curator can also open up to competent scholars the resources of personal collections not ordinarily available for use.

It is thus not always possible, or even desirable, for the curator of rare books to confine himself to the limits of the library building or the rare book collection. 
Gone is the day when the better mouse-trap would bring people beating a path. The demand for promotional activities in behalf of the rare book collection is a growing one. The library administrator has come to look upon the rare book collection as a means of attracting gifts and of obtaining publicity for the library as a whole. Such activities are valid as a function of the rare book collection, but only under the condition that all other basic needs of the collection have first been taken care of. Until the rare book collection is soundly organized and administered, its collections in shape and in order, and all such primary responsibilities met, it is dishonest for the curator of the collection to go out proclaming his or the library's wares. If such conditions are met, and if the rare book collection has a sufficient staff, there is a tremendous amount which can be done in interpreting and utilizing the rare book collection.

It is in large part such promotion which in my mind makes the difference between a merely adequate rare book collection and a really distinguished one. It is possible to limit the staff of the collection to the minimum number of people required to provide routine service, but if it is to bring acclaim to the university, opportunity and freedom for extra-mural activities on the part of the rare book staff should be provided. I know of one rare book room in a university library run competently enough by a staff of two persons. But you scarcely ever hear of that collection, which is not without many fine books.

It is necessary to make clear to the community, both within and outside the university, what the real purposes of a rare book collection are. We in a university pay a high price for the vices of those whose interest in rare books lies in fine morocco bindings or in commercial values and in the gamble of modern first editions. The resources of a rare book collection have manifold and more widely acceptable forms of appeal: to the student of texts in the many fields of science, literature, philosophy, and history; to the student of the graphic arts, and so on. One of the more pleasant opportunities for interpreting a collection which I have had this past year was that of addressing a group of practicing printers on the subject of a group of Bibles. As an example of what can be found in books of interest beyond their texts, the Bibles did provide a chance to discuss the various problems and the history of their printing, far beyond the limits of their subject matter. Such lectures, such talks, do much to break down the illusions regarding rare book collections which, in the long run, do them much harm, although the appeal of exclusiveness does on many an occasion pay dividends, particularly in terms of the wealthy book-collector.

At the same time, a distinction should be drawn between the interpretation of a collection to the public, and the use of his position by a curator of rare books as a means of subsidizing personal and private research. There are, to be sure, certain libraries in this country which provide positions which amount to the subsidizing of research, but I have yet to see a university rare book collection with a sufficient staff to justify the expenditure of one's working hours to one's personal advantage. The problem of handling the administrative responsibilities of a rare book collection should be enough to occupy one's days, while keeping up 
with current bibliographical and scholarly literature is more than enough for one's nights. Yet there are those of us for whom the urge to engage in research is sufficiently strong to make the problem of writing an academic one: how we find the time to do so I do not know. We just do, but it is a personal rather than a professional matter.

That the rôle of the curator should be that of a catalytic agent and stimulus to the publication of materials centering about the collection, rather than doing it himself, I think also follows. This is particularly true of manuscript materials, where I consider it distinctly unethical for the member of a library staff to seize upon them, editing them for his or her own personal advantage. Only in cases where one's own scholarly competence and knowledge fit one pre-eminently for the task, should one pre-empt such opportunities, rather than turning them over to a more proper person. The function of the librarian in a great university is primarily that of a custodian of the materials of research, an interpreter of their potentialities, and a stimulant to their use. The curator of rare books is performing an even more useful rôle in a university if he can get other people to carry out scholarly research than if he does it himself. To set such undertakings in motion is in fact often more difficult than the work itself, but if he is able to do it, he is contributing a great deal to the intellectual activity of the university, a very special type of service which is particularly and almost uniquely valuable.

If I have followed too literally André Gide's example in speaking largely in order to differ from more commonly accepted views, I have done so less from a sense of arrogance than from a belief that, since the rare book collection has grown up more as an expedient than as an objective, our previously accepted practices and tenets merit thorough re-examination. One of the principal dangers of the trend of the views which I have advanced, I will admit, is that the rare book collection may consider itself as the tail that wags the dog. It is necessary that a very fine balance be met between the rare book collection and the rest of the library. On the other hand, I think it rather healthy for each division of the library to consider itself of primary importance: only by such a confidence can each division fulfill its functions with the highest degree of effectiveness. Cooperation between units of a library is essential to effectiveness, though cooperation can also on occasion degenerate into a perfunctory observance of empty formulas and an interplay of personalities. Providing as much independence and responsibility within the unit itself as possible will in the long run accomplish as much for the library as a whole as for the division itself. The rather special problems of the rare book collection, in view of the materials handled, the type of service-bibliographical and otherwise-and the constant call for contacts with research workers and with collectors on their own levels, justify a high degree of independent organization, which will in turn greatly increase its prestige and stature. In such a fashion, I believe, will the rare book collection best serve its functions and achieve its widest scope in the research programs of the university and the community. 